\title{
GENDER STEREOTYPES IN THE ROMANIAN PUBLIC ADMINISTRATION
}

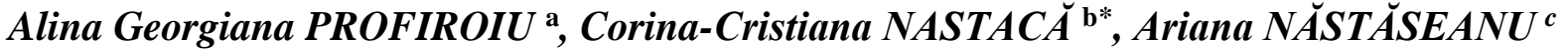 \\ ${ }^{a},{ }^{b}$ Bucharest University of Economic Studies, Romania, Faculty of Administration and Public Management, Romania \\ ${ }^{c}$ Bucharest University of Economic Studies, Management Doctoral School, Romania
}

\begin{abstract}
The present research aims to investigate the presence of gender stereotypes in the public administration of Romania, by observing if civil servants' associate effective and ineffective leadership behaviors with gender. The research methodology consists of a survey conducted in institutions from the public administration of Romania, using a questionnaire. The questionnaire was designed considering public institutions' peculiarities in order to explore the presence of gender stereotypes among civil servants' in a feminine working field. The sample contains ministries and subordinated institutions, Prefectures, and County Councils.

The study revealed the presence of gender stereotypes in the studied institutions because in men's case, effective types of leadership behaviors are found more in the image of male leaders. This association is not valid for women, who tend to consider effective leadership behaviors as specific to both categories of leaders. However, gender stereotypes are also present in female thinking, but to a lesser extent than in men's case. In the male respondents' case, a clear tendency to attribute effective leadership behaviors to the masculine gender could be observed. In terms of ineffective behaviors, they have been associated with both genders. This trend is less visible in the case of female respondents, who attributed effective behaviors as being specific either to both genders or to male leaders, rather to female leaders. However, there is a clear tendency of female leaders to associate inefficient behaviors with masculine gender, which leads to the idea that gender stereotypes are present in the studied institutions at a pretty high intensity.
\end{abstract}

KEYWORDS: feminine and masculine values, public administration, stereotypes.

\section{INTRODUCTION}

Even is gender equality is an important objective for the Member States, despite their efforts, none of the European countries succeeded in achieving it, in terms of women's access to decision-making positions in politics, public administration, or in other areas from the labor market. As an example, Global Data on National parliaments (IPU Parline, 2020) reveal that in most countries around the world, women are still under-represented in political positions that require high power of decision (as in Parliaments). The failure of achieving gender parity in leadership positions in the European countries is not explained by the lack of legislation on gender equality, but of other reasons which may still influence negatively the perception about female leaders. It is possible that even though women's participation in the labor market has increased, the role congruity theory (Eagly \& Karau, 2002) still has an impact on the collective thinking by generating and maintaining stereotypes against female leaders. This theory explains that society perceives an incongruity between women's characteristics and the qualities and results expected from leaders (Eagly \& Karau, 2002). Consequently, people associate men’s characteristics (named agentic traits) (Abele, 2003; Bakan,

\footnotetext{
* Corresponding author. Email address: cnastaca@gmail.com
} 
1966; Fiske \& Stevens, 1993, Broverman et al. 1972, Carli \& Eagly, 1999; Deaux \& Kite, 1993; Williams \& Best, 1990) with leader's image considering that those qualities are more suited for leading.

Gender stereotypes are still clearly observed in European societies and women still do not enjoy the same opportunities and equal access to the labor market and leadership positions as men do. Also, even if the concept of equal pay is clearly stated in national and European legislation labor market segregation in masculine and feminine professions leads to an unequal income level and the representation of women in politics and management positions is still low, consequently, the gender balance is still not in equilibrium.

Covid-19 pandemic brought many challenges regarding gender equality and opened a new path for leadership and gender studies as studies on gender stereotypes revealed than men's characteristics are better suited for managing crises (Dolan, 2014). Consequently, further studies might reveal a negative impact on the perception of female leaders. Also, the Covid-19 pandemic revealed the necessity for building and strengthening resilience in face of shocks. Beside the medical crises, many working fields are affected and recent studies showed that this pandemic could widen the gender gap and slow down the progress regarding equality (World Economic Forum, 2020, Alon et.al. 2020, McKinsey and Company, 2020). A study by McKinsey \& Company (2020) shows that women represent $39 \%$ in the whole economy of the world and that the feminine working areas (such as education, public administration, accommodation, and food services, wholesale and retail trade or arts and recreation) have been affected the most by this medical crisis. Beside the fact that the occupational segregation of the labor market had a negative impact on gender equality, leading to unequal incomes for men and women, now, due to the Covid-19 pandemic, the feminine organizations and working areas must find new modalities of strengthening resilience. As a response, the European Commission has developed a set of actions for the 2020-2025 period and a new strategy on gender equality, which laid the foundations for gender mainstreaming in all policies that will be developed in the European Union (European Commission, 2020).

Widening the gender gap will impact the global GDP growth (McKinsey \& Company, 2020), consequently, countries around the world must find a new path of progressing on gender equality and on fighting against gender stereotypes, as to succeed in coping with the economic crises that will follow after this pandemic.

In this respect, the present research aims to explore the presence of gender stereotypes in the public administration of Romania. Being a feminine working area, where almost $66 \%$ of the civil servants (National Agency of Civil Servants, 2019) with a major role in fighting the Covid-19 pandemic and in social and economic development, gender stereotypes will have a negative impact on the relationship between civil servants and their leaders and on developing both institutional and human resources' resilience. Consequently, this subject is a matter of interest in face of the new economic and social realities and will help at drawing conclusions and recommendations for achieving gender equality and fighting gender stereotypes in Romanian Public administration.

\section{THEORETICAL ASPECTS REGARDING GENDER EQUALITY AT THE EUROPEAN AND NATIONAL LEVEL}

In recent years, in Romania, women's representation in decision-making positions in politics and public administration has increased significantly as a result of the principles set out in gender policies from the European level that have been transposed into Romanian legislation. In the Member States as well as in Romania, certain progress can be observed regarding gender equality in the labor market or in terms of the gender pay gap. However, results are not as favorable as expected by the political leaders (European Commission, 2016). Even if gender inequalities in the labor market have declined significantly, gender equality has not been achieved and the gender balance in certain working areas is far from being in equilibrium. The labor market is still divided 
into male or female-dominated fields and professions. This situation does not only disadvantage women, but also men, who will be reluctant to work in a field that is not considered to be congruent with their gender role. Looking into the future and observing youth's study choices, the labor market will become more and more segregated.

Also, income differences between men and women persist and not due to the legislative framework. Romanian labor legislation, as in the other Member States, provides that equal work is remunerated at the same level, regardless of gender (Romanian Labor Code, 2019). However, occupational segregation, which leads to the division of the labor market into masculine and feminine occupations, increases these income disparities, as women are often employed in fields where the level of remuneration is low. At the EU's level, the pay gap between women and men remains at the same level as in 2014, with a woman earning on average $16 \%$ less per hour of work than a man (European Commission, 2019, National Institute of Statistics, 2019). This situation is not explained by the differences between women and men in terms of education, as in all Member States the number of female graduates from higher education (bachelor and master) exceeds the number of male graduates. The pay gap is explained by women's and men's choices in terms of fields of study and professions. At EU's level, is very clear that future graduates have different preferences regarding the studies to be followed, according to their gender. For example, men will choose to study in fields such as natural sciences, engineering, science, and technology, and women will choose to a greater extent, fields like humanities or medicine (European Institute for Gender Equality, 2019). In addition to these choices, the pay gap is often caused by the fact that women are represented in a very high proportion, in areas where incomes are low, such as social services, public administration, or education. Studies conducted at the European level (in Malta, Estonia, Latvia, Denmark, Spain or Finland) have revealed that although the number of women graduates of tertiary education is higher, they hold positions in sectors where the level of remuneration is low. However, it should be mentioned that women's representation in male-dominated professions, such as accounting or law, increased, but areas as engineering or science and technology remain highly masculine for almost 80\% (European Commission, 2019). These situations are caused by the presence of gender stereotypes and prejudices that lead to women's reluctance to pursue professions considered suitable for men and to inequalities regarding incomes.

Another problem is that occupational segregation is also observed within areas where, although women are well represented, the pay gap still exists because the management positions are held in a higher proportion by men (e.g. in education or public administration) (European Institute for Gender Equality, 2019).

The European Institute for Gender Equality (EIGE) presents annually, the gender equality index, comprising seven dimensions: power, money, time, knowledge, violence, health, and work. In 2019, Romania scored 54.5 points, with 12.9 points less than the European average. This score places Romania on the 25th position among the Member States, a score revealing that Romania's progress in terms of gender equality is being achieved at a slower pace. The score increased in the 2005-2017 period, but the progress has not been achieved in the same rhythm as in the European states. Even if the score is higher by 4.6 points compared to 2005-2017, Romania dropped one place in this ranking, deepening the gap with the Member States. Another negative aspect is that Romania's scores are below the European average for all seven dimensions. However, significant progress can be observed in terms of money and power, even if for the power dimension, Romania recorded the lowest score, with 13.1 points below the European average (EIGE, 2019).

The power dimension measures gender equality in decision-making positions in the economic, social, and political fields. In the political field, the dimension measures women's representation in Parliament, Government, regional councils (where appropriate), or in local councils. In the 20052018 period, the proportion of women who held ministerial positions increased significantly from $12 \%$ (2005) to 32\% (2018). Also, a higher representation of women in the national Parliament could be observed, from 11\% in 2005 to 19\% in 2018. Women's representation in local councils is very 
low, by only $16.9 \%$, while the European average is $28.5 \%$. More than that, women's proportion in the management of the large listed companies decreased from 13\% in 2005 to 10\% in 2018 (EIGE, 2019). The gender equality index does not refer to women's representation in decision-making positions in public administration, but the existing data reveal that in this field, Romania surpassed the European average, situating on a superior position (EIGE, 2019).

\section{THE MAIN STUDIES REGARDING GENDER STEREOTYPES AND THEIR INFLUENCE ON SUBORDINATES’ PERCEPTION OF THEIR LEADERS}

Stereotypes can diminish women's chances of holding positions with high power of decision. Stereotypes describe women as being sensitive, motivational, concerned about people's needs, helpful, kind, and nurturing (Abele, 2003; Bakan, 1966; Fiske \& Stevens, 1993; Broverman et al. 1972; Carli \& Eagly, 1999; Deaux \& Kite, 1993; Williams \& Best, 1990). These characteristics are considered common traits that make women more oriented towards leadership styles that will help them develop a strong relationship with subordinates. Instead, men are perceived as being aggressive, independent, decisive, and strong, making them achievement-oriented (Abele, 2003; Bakan, 1966; Fiske \& Stevens, 1993, Broverman, et al. 1972; Carli \& Eagly, 1999, Deaux \& Kite, 1993; Williams \& Best, 1990). These traits are named agentic traits. When women hold leadership positions, they are disadvantaged because of their common traits, because the idea of leadership is automatically associated with the agentic traits presented by men (Eagly \& Karau, 1991, 2002; Eagly, et al. 1995; Eagly, et al. 1992; Heilman, 2001; Heilman et al. 2004; Johnson et al. 2008). Another study by Schein and Muller (1992) showed that successful managers were considered to have masculine features. Also, Eagly and Karau, in a study conducted ten years later (2002) supported those results. The authors (Eagly and Karau, 2002) observed that the association between leaders and agentic traits still existed in collective thinking. This association impacts negatively the perception about female leaders because they either do not possess these agentic traits or if they do, it is considered unnaturally to behave in such a masculine manner.

However, some studies offer another perspective on the association of agentic qualities with leadership. For example, in a study by Powell et al. (2004), it was observed that the transactional leadership style is perceived in a more negative way than the transformational style. The transactional style is considered as being specific masculine, and the transformational one has been categorized as feminine (Van Engen et al. 2001). From this perspective, it can be considered that women using the transformational style would receive better evaluations from subordinates. However, the same authors observed that men who exhibit transformational behaviors were not evaluated negatively, although they behaved in a way inconsistent with their gender role. This situation is possible because the transformational style is considered the most effective leadership style (Lowe and Galen, 1996), consequently, subordinates will evaluate transformational leaders more positively, regardless of gender. However, the authors (Powell et al. 2004) bring a new perspective on the incongruity between gender and leadership, as there is a possibility that this incongruity will no longer exist in transformational leaders' case. Another explanation is that gender stereotypes are still present in collective thinking, being felt only in the perception of female leaders.

Research on gender stereotypes based on the assumption that respondents' gender could have an impact on leaders' evaluations has led to inconclusive and contradictory results. Some studies have shown that men have certain prejudices towards female leaders and for this reason, they will evaluate them in a less positive way (Ayman et al. 2009; Norris \& Wylie, 1995; Tomkiewicz \& Adeyemi-Bello, 1995). Other research has suggested that women have more negative perceptions of female leaders than men (Garcia-Retamero \& López-Zafra, 2006; Parks-Stamm et al. 2008; Rudman, 1998). Other authors could not observe any difference between the way leaders are perceived, depending on their gender (Johnson et al. 2008), an opinion supported by more recent 
studies, where no correlation between respondents' gender and leaders' evaluations could be observed (Byron, 2007).

Authors Petty and Miles (1976) researched subordinates' perceptions of their leaders, compared by their gender. The study showed that female leaders who used a feminine leadership style were much better evaluated than men who used those styles. Similarly, subordinates were more satisfied with male leaders who used masculine leadership styles than with female leaders who adopted those leadership styles. Also, Eagly, Makhijani, and Klonsky (1992) found that male leaders were evaluated more positively only if female leaders used masculine leadership styles. This finding is favorable to women, as it shows that negative assessments are not caused by gender, but by the use of leadership styles that are considered inappropriate for their gender.

Moreover, it has been observed that women are rated more negatively when expressing anger, nonfeminine behavior (Glomb \& Hulin, 1997; Lewis, 2000). The results of the aforementioned studies are consistent with the role congruence theory and show that subordinates have a certain genderrelated leadership prototype. Consequently, leaders who behave following their gender roles will be perceived much more positively. These perceptions are not in women's favor, because the idea of leadership is associated with masculine values and women will consider it necessary to adopt masculine behaviors when they hold leadership positions.

In addition to the incongruity between leader role and the feminine gender, women also will be perceived negatively is they do not behave in a manner consistent with their gender role, a role that is not associated with leadership.

In another study, Schein $(1973,1975)$ asked women and men in management positions to categorize certain characteristics as specific to men, women, or middle managers. The results showed that the people in the sample associated the characteristics that should be specific to managers with those of men and much less with the feminine gender. This finding suggests that the expectations of men are similar to the expectations of leaders. Research conducted 15 years later has led to the same result (Brenner et al. 1989; Heilman et al. 1989). However, another study showed, that female leaders who used the task-oriented leadership style (considered to be masculine) were perceived as more effective leaders than those who used a style-oriented towards interpersonal relations but were less liked by subordinates (Forsyth et al. 1997).

Other research aiming to explore the impact of gender o subordinates' perception of their leaders' behaviors has led to slightly different results than those found in previous studies (Powell et al. 2004). The authors studied how leaders who use either the transformational leadership style or the transactional style are perceived in terms of their efficiency and attitude. The results showed that men who used the transformational leadership style received better evaluations than female leaders who used the same style. The result is in contradiction with previous studies because the transformational style is considered to be a feminine style and theoretically, men should not have been perceived in a more positive way than women. Moreover, female leaders who used the transactional leadership style were assessed less positively than men who used this style. This result is consistent with the role congruence theory, because the transactional leadership style is considered a masculine style, and women were perceived as behaving inconsistently with their gender. The study revealed a very interesting aspect regarding gender issues: when male leaders adopt a leadership style considered feminine, they can be appreciated positively but this appreciation does not exist when women use styles considered to be masculine (Powell et al 2004). The mentioned studies reveal the impact of gender stereotypes on the perception that subordinates have on their leaders. In this respect, the present study aims to explore if these results can be observed in the present, in the public administration, an environment where women dominate. If gender stereotypes can be observed at a high intensity, this situation will affect the leader-member relationship and the effectiveness of leadership. 


\section{RESEARCH METHODOLOGY}

The present study aims to explore the presence of gender stereotypes in the institutions from the public administration of Romania to observe if civil servants' associate leadership characteristics and behaviors with gender.

The study started with the following hypotheses: the presence of gender stereotypes will be observed by the tendency of respondents to attribute effective leadership behaviors to leaders of the same gender and inefficient behaviors to leaders of the opposite gender.

The research methodology consists of a survey conducted in institutions from the public administration of Romania, using a questionnaire. The questionnaire was designed considering public institutions' peculiarities to explore the presence of gender stereotypes among civil servants' in a feminine working field. The sample contains ministries and subordinated institutions, Prefectures, and County Councils. The exhaustive sampling method was used, as the questionnaire was sent to all ministries (22 ministries), Prefectures (42), and County Councils (41) from Romania. In the subordinated institutions' case, a simple random sampling method was used as one institution for each ministry was chosen (22 subordinated institutions). The total number of respondents was 766 civil servants.

The questionnaire was sent via email to all the institutions included in the sample along with a request in which the participants were asked to express their agreement of participation in the study. The potential respondents were assured of confidentiality and were asked not to reveal their names. The data was collected in January-February 2020. The gathered data were processed in SPSS

The first part of the questionnaire contains five identification questions. These refer to the held public position (executive and management), respondent's gender, Director's gender, age, and seniority in public office. Starting from studies that focused on masculine and feminine values in organizations, on the perception of male and female leaders, as well as on the impact of gender stereotypes on leaders' assessments and leadership styles (Offermann et al. 1994, Johnson et al. et al., 2008, Abele, 2003; Bakan, 1966; Fiske \& Stevens, 1993; Broverman et al. 1972; Carli \& Eagly, 1999; Deaux \& Kite, 1993; Williams \& Best, 1990; Eagly \& Karau, 2002), in the second part of the questionnaire, 30 items representing different types of leadership behaviors specific only to transformational, transactional and laissez-faire leaders were presented. Respondents were asked to associate those behaviors with masculine, feminine or both genders.

\subsection{The main characteristics of the sample}

The civil servants included in the sample were executive civil servants and civil servants from management occupying positions of head of office and head of department. Regarding the public positions held by them, according to the level of the attributions, 138 persons (18\%) hold positions of head of office and head of department, and 628 (82\%) were executive civil servants.

Regarding participants' age, 16\% (123) were between 20 and 35 years old, 56\% (429) were between 35 and 50 years old and 28\% (213) were between 50 and 65\% old. Only one respondent was over 65 years old.

Concerning respondents' distribution according to their seniority in the institutions included in the sample, 8\% (59) were beginners with seniority of $0-1$ years, $26 \%$ (197) were assistant civil servants with seniority between 1 and 5 years, 8\% (61) were civil servants on principle grade with seniority between 5 and 7 years and the majority, 58\% (448), had seniority of more than 7 years, standing at the last professional-grade, namely, the superior grade.

Regarding respondents' distribution by their gender, 69.6\% (533) were women and 30.4\% (233) were men. The gender structure of the population participating in the study was similar to the gender structure of the body of civil servants, where $65.94 \%$ are women and $34.06 \%$ are men (National Agency of Civil Servants, 2019). Regarding Directors' gender, 56.8\% (435) of the respondents worked in Directorates led by female Directors, and 43.2\% (331) by men. 


\section{GENDER STEREOTYPES IN ROMANIA’S PUBLIC ADMINISTRATION}

Research aiming to investigate leadership prototypes (Offermann et al. 1994, Johnson et al. 2008) revealed that, subordinates associate different characteristics to their leaders depending on leaders' gender. To test the theory of implicit leadership (ILT), researchers (Offermann et al. 1994) designed a questionnaire with 41 items, aiming to analyze the existence of these prototypes, using eight dimensions: power, masculinity, tyranny, charisma, intelligence, dedication, sensitivity, attractiveness. The authors noted that power, masculinity, and tyranny are considered characteristics specific to male leaders, sensitivity, and attractiveness are associated with female leaders, while charisma, intelligence, and dedication are considered characteristics associated with both genders. Moreover, it has been observed that the attribution of these characteristics is generated by the existence of gender stereotypes (Johnson et al. 2008). Other studies have further investigated the causes behind the existence of these leadership prototypes and discovered that one cause would be the presence of feminine and masculine values in organizational cultures, the latter dominating in organizations from Western societies (Marshall, 1993, Cole, 2004). These types of values have an impact on the emergence of leadership prototypes and led to characteristics that are supposed to be typically feminine or masculine and then to the emergence of characteristics associated with leaders' personalities. These masculine values suppose that men possess agentic traits and women, common traits. These agentic traits were also identified in leaders' necessary characteristics, which led to an automatic association of leaders with men (Abele, 2003; Bakan, 1966; Fiske \& Stevens, 1993, Broverman et al. 1972, Carli \& Eagly, 1999; Deaux \& Kite, 1993; Williams \& Best, 1990, Eagly \& Karau, 2002). All these studies have revealed the impact of gender stereotypes, as these leadership prototypes are generated by stereotypical thinking and by society's perception of gender roles and behaviors that women and men are supposed to manifest.

Starting from the mentioned studies, the present study aims to investigate the presence of gender stereotypes in the public administration of Romania. Given women's high representation in Romanian public administration (over 60\%), these gender stereotypes should be observed at a lower intensity. Unlike previous studies, in order to measure the presence of gender stereotypes in the studied institutions, 30 statements that represent behaviors and characteristics specific to transformational and transactional leaders were created. From the 30 items, five represented inefficient leadership behaviors. The pointing start in designing these statements were the conceptualizations of the transformational and transactional styles (Burns, 1978, Bass, 2008), as identified in the literature review. Also, five statements represent passive-avoidant behaviors, typical for laissez-faire leaders (Eagly et. al, 2003). Respondents were asked to attribute these behaviors and characteristics as being typically feminine, typically masculine, or neutral (specific to both men and women).

Table 1 presents the distribution of civil servants' responses regarding the association between gender and leadership behaviors. It can be observed that only four leadership behaviors (colored in red) were considered to be typically feminine, by a higher proportion of respondents (Being constantly concerned for subordinates' needs., Supporting subordinates in difficult situations in both professional and personal life, Stimulating subordinates' creativity, and encouraging them to solve problems in an innovative manner, Preferring to prevent problems rather than solve them). The first two behaviors can be associated with the leadership prototype called sensitivity (Offermann et al. 1994, Johnson et al., 2008), considered to be a specific characteristic of female leaders. The third behavior is also identified in the literature as a common behavior, typically feminine (Abele, 2003; Bakan, 1966; Fiske \& Stevens, 1993, Broverman, et al. 1972; Carli \& Eagly, 1999; Deaux \& Kite, 1993; Williams \& Best, 1990, Eagly \& Karau, 2002). The fourth behavior is specific to transformational leaders, the transformational style being considered a feminine one. 
Table 1. The distribution of civil servants' responses regarding the association between gender and leadership behaviors

\begin{tabular}{|c|c|c|c|}
\hline Leadership behaviors and characteristics & $\mathbf{F}$ & $\mathbf{M}$ & Neutral \\
\hline Being constantly concerned about subordinates' needs. & $40.99 \%$ & $21.54 \%$ & $37.47 \%$ \\
\hline Supporting subordinates in difficult situations in both professional and personal life. & $41.64 \%$ & $20.63 \%$ & $37.73 \%$ \\
\hline Encouraging subordinates to work in teams. & $18.95 \%$ & $37.39 \%$ & $43.66 \%$ \\
\hline Discussing in specific terms to the persons responsible for achieving performance targets. & $32.38 \%$ & $29.77 \%$ & $37.86 \%$ \\
\hline Being open to collaboration with subordinates and colleagues. & $24.80 \%$ & $33.81 \%$ & $41.38 \%$ \\
\hline Appreciating and considering subordinates' ideas. & $27.81 \%$ & $30.16 \%$ & $42.04 \%$ \\
\hline Involving subordinates in the decision-making process. & $26.37 \%$ & $33.03 \%$ & $40.60 \%$ \\
\hline Presenting a high level of self-confidence. & $17.49 \%$ & $44.78 \%$ & $37.73 \%$ \\
\hline Presenting a high level of trust in subordinates. & $21.93 \%$ & $37.73 \%$ & $40.34 \%$ \\
\hline Involving directly in solving problems. & $30.42 \%$ & $26.37 \%$ & $43.21 \%$ \\
\hline Taking responsibility for his/her own mistakes. & $28.59 \%$ & $32.11 \%$ & $39.30 \%$ \\
\hline Failing to take responsibility for his/her own mistakes. & $29.63 \%$ & $34.60 \%$ & $35.77 \%$ \\
\hline $\begin{array}{l}\text { Stimulating subordinates' creativity and encouraging them to solve problems in an } \\
\text { innovative manner. }\end{array}$ & $37.60 \%$ & $26.63 \%$ & $35.77 \%$ \\
\hline Motivating subordinates using non-financial techniques. & $32.11 \%$ & $28.85 \%$ & $39.03 \%$ \\
\hline Developing a close relationship with subordinates, even outside working hours. & $30.68 \%$ & $31.72 \%$ & $37.60 \%$ \\
\hline $\begin{array}{l}\text { Encouraging subordinates to develop professionally (to attend courses or new forms of } \\
\text { education, to participate in experience changes with other institutions from the country or } \\
\text { from abroad). }\end{array}$ & $26.37 \%$ & $29.90 \%$ & $43.73 \%$ \\
\hline $\begin{array}{l}\text { Explaining subordinates what have they done wrong and how to approach the problem } \\
\text { correctly. }\end{array}$ & $33.81 \%$ & $26.37 \%$ & $39.82 \%$ \\
\hline Encouraging subordinates and helping them to build up self-confidence. & $30.55 \%$ & $29.50 \%$ & $39.95 \%$ \\
\hline $\begin{array}{l}\text { Considering that his/her point of view to be the best and not take into account subordinates? } \\
\text { opinions and suggestions. }\end{array}$ & $28.59 \%$ & $36.42 \%$ & $34.99 \%$ \\
\hline Charisma & $23.37 \%$ & $35.38 \%$ & $41.25 \%$ \\
\hline Explain the purpose of the assigned tasks. & $32.94 \%$ & $27.19 \%$ & $39.87 \%$ \\
\hline Being constantly informed about what is new in their working area. & $28.98 \%$ & $26.24 \%$ & $44.78 \%$ \\
\hline Being uninvolved in the problem-solving process. & $25.85 \%$ & $36.95 \%$ & $37.21 \%$ \\
\hline Involving in solving problems only when they get severe. & $23.63 \%$ & $39.82 \%$ & $36.55 \%$ \\
\hline Preferring to prevent problems rather than solve them. & $37.60 \%$ & $25.46 \%$ & $36.95 \%$ \\
\hline Being objective when evaluating his/her subordinates. & $20.00 \%$ & $39.87 \%$ & $40.13 \%$ \\
\hline Being subjective when evaluating his/her subordinates. & $37.52 \%$ & $24.44 \%$ & $38.04 \%$ \\
\hline Using delegation as a method to appoint assignments to subordinates. & $20.63 \%$ & $35.38 \%$ & $43.99 \%$ \\
\hline Being ambitious. & $21.67 \%$ & $32.90 \%$ & $45.43 \%$ \\
\hline Supporting subordinates to cope with their personal problems. & $35.90 \%$ & $22.72 \%$ & $41.38 \%$ \\
\hline
\end{tabular}

Source: Authors, 2020

Regarding behaviors that could be typically masculine, only three of the presented characteristics and behaviors were considered by a higher number of respondents as being specific to male leaders (Presenting a high level of self-confidence, Considering that his/her point of view to be the best and 
not take into account subordinates' opinions and suggestions, Involving in solving problems only when they get severe). The first two behaviors can be associated with the leadership prototype, called power, which has been considered in previous studies, as being an agentic trait, characteristic to male leaders (Offermann et al. 1994, Johnson et al. 2008). The latter behavior is specific to laissez-faire leaders and previous studies revealed that men exhibit more than women, this type of behavior (Eagly et al. 2003, Powell et al. 2004).

Concerning the neutral behaviors, 23 out of the presented characteristics were considered from a higher number of respondents as being specific to both male and female leaders (in a proportion between 35 and 45\%). These neutral behaviors are specific to transformational, transactional, and laissez-faire leaders. Given the fact that most of them are considered to be rather specific to both genders, it is possible that in the study institutions, gender stereotypes to be present at a lower intensity. Moreover, previous studies (Eagly et. al, 2003, Powell et. al, 2003, Eagly \& Karau, 2002) revealed that women are considered to practice the transformational leadership style to a greater extent, while men are considered to be more transactional and less involved in the leading process. These perceptions are influenced by gender stereotypes, and considering the present findings, it is also possible that in the institutions included in the sample, these manners of perceiving leaders according to their gender will not be so obvious, because gender stereotypes seem to be less present.

To test the hypothesis of the research (The presence of gender stereotypes will be observed by the tendency of respondents to attribute effective leadership behaviors to leaders of the same gender and inefficient behaviors to leaders of the opposite gender) the frequencies of civil servants' responses regarding the association between gender and leadership behaviors were computed, by respondents' gender. The purpose is to observe whether they are impartial or tend to associate effective leadership behaviors with leaders of the same gender and ineffective behaviors with leaders of the opposite gender.

Table 2. The frequencies of civil servants' responses regarding the association between gender and leadership behaviors, were computed, by respondents' gender

\begin{tabular}{|c|c|c|c|c|c|c|}
\hline \multirow{2}{*}{$\begin{array}{l}\text { Respondents' gender } \\
\text { Leadership behaviors and characteristics }\end{array}$} & \multicolumn{3}{|c|}{ Masculin } & \multicolumn{3}{|c|}{ Feminine } \\
\hline & F & $\mathbf{M}$ & Neutral & $\mathbf{F}$ & $\mathbf{M}$ & Neutral \\
\hline Being constantly concerned about subordinates' needs. & $\begin{array}{l}27.07 \\
\%\end{array}$ & $\begin{array}{l}43.23 \\
\%\end{array}$ & $29.69 \%$ & $\begin{array}{l}47.34 \\
\%\end{array}$ & $\begin{array}{l}18.06 \\
\%\end{array}$ & $34.60 \%$ \\
\hline $\begin{array}{l}\text { Supporting subordinates in difficult situations in both professional } \\
\text { and personal life. }\end{array}$ & $\begin{array}{l}26.64 \\
\%\end{array}$ & $\begin{array}{l}42.36 \\
\%\end{array}$ & $31.00 \%$ & $\begin{array}{l}48.48 \\
\%\end{array}$ & $\begin{array}{l}16.16 \\
\%\end{array}$ & $35.36 \%$ \\
\hline Encouraging subordinates to work in teams. & $\begin{array}{l}12.66 \\
\%\end{array}$ & $\begin{array}{l}42.79 \\
\%\end{array}$ & $44.54 \%$ & $\begin{array}{l}21.67 \\
\%\end{array}$ & $\begin{array}{l}34.41 \\
\%\end{array}$ & $43.92 \%$ \\
\hline $\begin{array}{l}\text { Discussing in specific terms to the persons responsible for achieving } \\
\text { performance targets. }\end{array}$ & $\begin{array}{l}20.96 \\
\%\end{array}$ & $\begin{array}{l}40.61 \\
\%\end{array}$ & $38.43 \%$ & $\begin{array}{l}38.02 \\
\%\end{array}$ & $\begin{array}{l}25.67 \\
\%\end{array}$ & $36.31 \%$ \\
\hline Being open to collaboration with subordinates and colleagues. & $\begin{array}{l}17.47 \\
\%\end{array}$ & $\begin{array}{l}41.05 \\
\%\end{array}$ & $41.48 \%$ & $\begin{array}{l}28.33 \\
\%\end{array}$ & $\begin{array}{l}30.42 \\
\%\end{array}$ & $41.25 \%$ \\
\hline Appreciating and considering subordinates' ideas. & $\begin{array}{l}20.52 \\
\%\end{array}$ & $\begin{array}{l}41.05 \\
\%\end{array}$ & $38.43 \%$ & $\begin{array}{l}31.37 \\
\%\end{array}$ & $\begin{array}{l}26.43 \\
\%\end{array}$ & $42.21 \%$ \\
\hline Involving subordinates in the decision-making process. & $\begin{array}{l}20.09 \\
\%\end{array}$ & $\begin{array}{l}42.79 \\
\%\end{array}$ & $37.12 \%$ & $\begin{array}{l}29.90 \\
\%\end{array}$ & $\begin{array}{l}30.86 \\
\%\end{array}$ & $39.24 \%$ \\
\hline Presenting a high level of self-confidence. & $\begin{array}{l}13.54 \\
\%\end{array}$ & $\begin{array}{l}37.55 \\
\%\end{array}$ & $48.91 \%$ & $\begin{array}{l}19.77 \\
\%\end{array}$ & $\begin{array}{l}42.97 \\
\%\end{array}$ & $37.26 \%$ \\
\hline Presenting a high level of trust in subordinates. & $\begin{array}{l}15.72 \\
\%\end{array}$ & $\begin{array}{l}39.30 \\
\%\end{array}$ & $44.98 \%$ & $\begin{array}{l}25.29 \\
\%\end{array}$ & $\begin{array}{l}34.41 \\
\%\end{array}$ & $40.30 \%$ \\
\hline Involving directly in solving problems. & $\begin{array}{l}18.34 \\
\%\end{array}$ & $\begin{array}{l}43.67 \\
\%\end{array}$ & $37.99 \%$ & $\begin{array}{l}36.12 \\
\%\end{array}$ & $\begin{array}{l}21.10 \\
\%\end{array}$ & $42.78 \%$ \\
\hline
\end{tabular}




\begin{tabular}{|c|c|c|c|c|c|c|}
\hline \multirow{2}{*}{$\begin{array}{l}\text { Respondents' gender } \\
\text { Leadership behaviors and characteristics }\end{array}$} & \multicolumn{3}{|c|}{ Masculin } & \multicolumn{3}{|c|}{ Feminine } \\
\hline & $\mathbf{F}$ & $\mathbf{M}$ & Neutral & $\mathbf{F}$ & $\mathbf{M}$ & Neutral \\
\hline Taking responsibility for his/her own mistakes. & $\begin{array}{l}17.03 \\
\%\end{array}$ & $\begin{array}{l}41.92 \\
\%\end{array}$ & $41.05 \%$ & $\begin{array}{l}34.03 \\
\%\end{array}$ & $\begin{array}{l}28.14 \\
\%\end{array}$ & $37.83 \%$ \\
\hline Failing to take responsibility for his/her own mistakes. & $\begin{array}{l}34.93 \\
\%\end{array}$ & $\begin{array}{l}38.86 \\
\%\end{array}$ & $26.20 \%$ & $\begin{array}{l}27.19 \\
\%\end{array}$ & $\begin{array}{l}38.78 \\
\%\end{array}$ & $34.03 \%$ \\
\hline $\begin{array}{l}\text { Stimulating subordinates' creativity and encouraging them to solve } \\
\text { problems in an innovative manner. }\end{array}$ & $\begin{array}{l}24.89 \\
\%\end{array}$ & $\begin{array}{l}40.61 \\
\%\end{array}$ & $34.50 \%$ & $\begin{array}{l}43.73 \\
\%\end{array}$ & $\begin{array}{l}23.19 \\
\%\end{array}$ & $33.08 \%$ \\
\hline Motivating subordinates using non-financial techniques. & $\begin{array}{l}27.51 \\
\%\end{array}$ & $\begin{array}{l}40.17 \\
\%\end{array}$ & $32.31 \%$ & $\begin{array}{l}34.60 \\
\%\end{array}$ & $\begin{array}{l}27.19 \\
\%\end{array}$ & $38.21 \%$ \\
\hline $\begin{array}{l}\text { Developing a close relationship with subordinates, even outside } \\
\text { working hours. }\end{array}$ & $\begin{array}{l}22.27 \\
\%\end{array}$ & $\begin{array}{l}37.99 \\
\%\end{array}$ & $39.74 \%$ & $\begin{array}{l}34.60 \\
\%\end{array}$ & $\begin{array}{l}28.33 \\
\%\end{array}$ & $37.07 \%$ \\
\hline $\begin{array}{l}\text { Encouraging subordinates to develop professionally (to attend } \\
\text { courses or new forms of education, to participate in experience } \\
\text { changes with other institutions from the country or from abroad). }\end{array}$ & $\begin{array}{l}20.09 \\
\%\end{array}$ & $\begin{array}{l}44.54 \\
\%\end{array}$ & $35.37 \%$ & $\begin{array}{l}29.28 \\
\%\end{array}$ & $\begin{array}{l}27.57 \\
\%\end{array}$ & $43.16 \%$ \\
\hline $\begin{array}{l}\text { Explaining subordinates what have they done wrong and how to } \\
\text { approach the problem correctly. }\end{array}$ & $\begin{array}{l}25.76 \\
\%\end{array}$ & $\begin{array}{l}42.79 \\
\%\end{array}$ & $31.44 \%$ & $\begin{array}{l}37.64 \\
\%\end{array}$ & $\begin{array}{l}24.14 \\
\%\end{array}$ & $38.21 \%$ \\
\hline $\begin{array}{l}\text { Encouraging subordinates and helping them to build up self- } \\
\text { confidence. }\end{array}$ & $\begin{array}{l}18.34 \\
\%\end{array}$ & $\begin{array}{l}44.10 \\
\%\end{array}$ & $37.55 \%$ & $\begin{array}{l}36.31 \\
\%\end{array}$ & $\begin{array}{l}26.05 \\
\%\end{array}$ & $37.64 \%$ \\
\hline $\begin{array}{l}\text { Considering that his/her point of view to be the best and not take } \\
\text { into account subordinates' opinions and suggestions. }\end{array}$ & $\begin{array}{l}32.75 \\
\%\end{array}$ & $\begin{array}{l}36.68 \\
\%\end{array}$ & $30.57 \%$ & $\begin{array}{l}27.00 \\
\%\end{array}$ & $\begin{array}{l}39.54 \\
\%\end{array}$ & $33.46 \%$ \\
\hline Charisma & $\begin{array}{l}20.96 \\
\%\end{array}$ & $\begin{array}{l}41.92 \\
\%\end{array}$ & $37.12 \%$ & $\begin{array}{l}24.90 \\
\%\end{array}$ & $\begin{array}{l}34.60 \\
\%\end{array}$ & $40.49 \%$ \\
\hline Explain the purpose of the assigned tasks. & $\begin{array}{l}25.76 \\
\%\end{array}$ & $\begin{array}{l}40.17 \\
\%\end{array}$ & $34.06 \%$ & $\begin{array}{l}36.69 \\
\%\end{array}$ & $\begin{array}{l}23.95 \\
\%\end{array}$ & $39.35 \%$ \\
\hline Being constantly informed about what is new in their working area. & $\begin{array}{l}22.27 \\
\%\end{array}$ & $\begin{array}{l}44.10 \\
\%\end{array}$ & $33.62 \%$ & $\begin{array}{l}32.13 \\
\%\end{array}$ & $\begin{array}{l}23.00 \\
\%\end{array}$ & $44.87 \%$ \\
\hline Being uninvolved in the problem-solving process. & $\begin{array}{l}36.68 \\
\%\end{array}$ & $\begin{array}{l}37.55 \\
\%\end{array}$ & $25.76 \%$ & $\begin{array}{l}20.91 \\
\%\end{array}$ & $\begin{array}{l}42.78 \\
\%\end{array}$ & $36.31 \%$ \\
\hline Involving in solving problems only when they get severe. & $\begin{array}{l}32.31 \\
\%\end{array}$ & $\begin{array}{l}35.81 \\
\%\end{array}$ & $31.88 \%$ & $\begin{array}{l}19.96 \\
\%\end{array}$ & $\begin{array}{l}43.92 \\
\%\end{array}$ & $36.12 \%$ \\
\hline Preferring to prevent problems rather than solve them. & $\begin{array}{l}28.38 \\
\%\end{array}$ & $\begin{array}{l}37.55 \\
\%\end{array}$ & $34.06 \%$ & $\begin{array}{l}42.21 \\
\%\end{array}$ & $\begin{array}{l}21.86 \\
\%\end{array}$ & $35.93 \%$ \\
\hline Being objective when evaluating his/her subordinates. & $\begin{array}{l}13.97 \\
\%\end{array}$ & $\begin{array}{l}38.86 \\
\%\end{array}$ & $47.16 \%$ & $\begin{array}{l}22.96 \\
\%\end{array}$ & $\begin{array}{l}36.24 \\
\%\end{array}$ & $40.80 \%$ \\
\hline Being subjective when evaluating his/her subordinates. & $\begin{array}{l}42.36 \\
\%\end{array}$ & $\begin{array}{l}38.43 \\
\%\end{array}$ & $19.21 \%$ & $\begin{array}{l}35.29 \\
\%\end{array}$ & $\begin{array}{l}26.94 \\
\%\end{array}$ & $37.76 \%$ \\
\hline $\begin{array}{l}\text { Using delegation as a method to appoint assignments to } \\
\text { subordinates. }\end{array}$ & $\begin{array}{l}14.85 \\
\%\end{array}$ & $\begin{array}{l}42.79 \\
\%\end{array}$ & $42.36 \%$ & $\begin{array}{l}23.76 \\
\%\end{array}$ & $\begin{array}{l}32.32 \\
\%\end{array}$ & $43.92 \%$ \\
\hline Being ambitious. & $\begin{array}{l}21.83 \\
\%\end{array}$ & $\begin{array}{l}42.36 \\
\%\end{array}$ & $35.81 \%$ & $\begin{array}{l}22.24 \\
\%\end{array}$ & $\begin{array}{l}31.56 \\
\%\end{array}$ & $46.20 \%$ \\
\hline Supporting subordinates to cope with their personal problems. & $\begin{array}{l}24.45 \\
\%\end{array}$ & $\begin{array}{l}44.10 \\
\%\end{array}$ & $31.44 \%$ & $\begin{array}{l}40.87 \\
\%\end{array}$ & $\begin{array}{l}19.20 \\
\%\end{array}$ & $39.92 \%$ \\
\hline
\end{tabular}

Source: Authors, 2020

Table 2 presents the frequencies of civil servants' responses comparatively, by respondents' gender. The analysis started from the assumption that respondents' gender could influence the manner in which they associate those behaviors, considering their personal experiences with female and male leaders. Moreover, due to the high degree of subjectivism that could affect the answers given, it is 
possible that a larger number of respondents would attribute effective behaviors to leaders of the same gender and consider them less specific to both genders.

It can be observed that 21 behaviors, were considered as being typically masculine, by a higher proportion (between 36 and 45\%) of male respondents Only one behavior (Being subjective when evaluating his/her subordinates) has been considered as being rather feminine. Around $43 \%$ of male respondents considered that subjectivism in the evaluation of subordinates is typical feminine behavior. This association between feminine gender and subjectivism reveals a negative perception of women leaders. Four behaviors were considered specifically masculine or to both genders by an approximately equal proportion of respondents (between 37\% and 45\%). Only three behaviors were associated with both genders from a higher number of civil servants (Presenting a high level of selfconfidence, presenting a high level of trust in subordinates, being objective when evaluating his/her subordinates).

Regarding the five inefficient behaviors, three of them were considered as rather being typically masculine (Failing to take responsibility for his/her own mistakes, considering that his/her point of view to be the best and not take into account subordinates' opinions and suggestions, involving in solving problems only when they get severe). One behavior was associated more with female leaders (Being subjective when evaluating his/her subordinates) and another (Being uninvolved in the problem-solving process) was considered either masculine or feminine by approximately the same proportion of respondents (37.55\% vs. 36.88\%).

On average, around $41 \%$ of the respondents associated the presented behaviors with masculine gender. The high proportion of male respondents who attributed these behaviors mostly to leaders on the same gender reveals the presence of gender stereotypes. Men's tendency of associating most of the effective leadership behaviors with leaders of the same gender reveals a high degree of subjectivism in civil servants' responses and the existence of prejudices towards female leaders. By associating effective behaviors with the masculine gender to a greater extent, means that indirectly, the perception towards male leaders is better. Even if declaratively, respondents are not interested in the gender of their leaders, the way they attribute leadership behaviors, still shows a preference for male leaders and a higher level of appreciation for them.

Analyzing how women associated the presented behaviors, it could be observed that only in four cases (Being constantly concerned for subordinates' needs, Supporting subordinates in difficult situations in both professional and personal life, Stimulating subordinates' creativity, and encouraging them to solve problems in an innovative manner, Preferring to prevent problems rather than solve them), they considered in a higher proportion, that these behaviors are specific to female leaders (between 42 and 49\%). Five behaviors (Discussing in specific terms to the persons responsible for achieving performance targets, Explaining subordinates what have they done wrong and how to approach the problem correctly, Encouraging subordinates and helping them to build up self-confidence, Being subjective when evaluating his/her subordinates, Supporting subordinates to cope with their personal problems) were associated either with feminine gender or with both men and women by almost the same number of civil servants. Regarding the ineffective behaviors, four out of five (Failing to take responsibility for his/her own mistakes, considering that his/her point of view to be the best and not take into account subordinates' opinions and suggestions, being uninvolved in the problem-solving process, involving in solving problems only when they get severe) were associated rather with a masculine gender (between 38 and $44 \%$ of female respondents had this opinion). The rest of the behaviors were attributed to both genders by a larger number of respondents than those who considered them to be specifically feminine or masculine (between $33 \%$ and $47 \%$ ). On average, approximately $32 \%$ of female respondents attributed the presented behaviors to female leaders. Also, female respondents have a greater tendency to attribute leadership behaviors to both categories of leaders, while male leaders are more likely to attribute effective behaviors to leaders on the same gender. How women associated the leadership behaviors 
revealed that for them, leaders' gender is not very important. However, gender stereotypes can also be observed in women's way of thinking, but to a lesser extent than in men's case.

The results show the presence of gender stereotypes in the studied institutions and that in men's case, effective leadership behaviors are found more in the image of male leaders. This association is not valid for women, who tend to associate leadership behaviors with both genders. Women can evaluate their leaders' behaviors by other criteria, being more objective and less influenced by gender roles, stereotypes, masculine and feminine values.

The results are consistent with studies that revealed that men have certain prejudices towards female leaders and therefore they would evaluate them less positively (Ayman et al. 2009; Norris and Wylie, 1995; Tomkiewicz \& Adeyemi- Bello, 1995). Also, the results partially validate the first hypothesis of the study because in men's case, there is a clear tendency to associate effective leadership behaviors with leaders of the same gender. In terms of ineffective behaviors, they have been associated with both genders. This tendency is less observed in women's case, who attributed effective behaviors to either both genders or to male leaders rather than to female leaders. However, there is a clear tendency of female leaders to associate inefficient behaviors with masculine gender, which leads to the idea of gender stereotypes in the studied institutions. Moreover, how women have attributed the effective leadership behaviors may be driven by a greater degree of objectivity and a lower level of prejudice and stereotypical thinking. Another possibility would be, as other authors have observed, that women have more negative perceptions of female leaders than men (Garcia-Retamero and López-Zafra, 2006; Parks-Stamm et al., 2008; Rudman, 1998) and for this reason, a clear tendency to associate effective behaviors with the feminine gender could not be observed.

\section{CONCLUSIONS}

The study revealed the presence of gender stereotypes in the studied institutions and that in men's case, effective types of leadership behaviors are found more in the image of male leaders. This association is not valid for women, who tend to consider effective leadership behaviors as specific to both categories of leaders. It is possible for women to evaluate the behaviors of their leaders according to other criteria, being more objective and less influenced by gender roles, stereotypes, or masculine and feminine values. How female leaders associate leadership behaviors show that the leaders' gender is not very important for them. However, gender stereotypes are also present in female thinking, but to a lesser extent than in men's case. In male respondents' case, a clear tendency to attribute effective leadership behaviors to the masculine gender, could be observed. In terms of ineffective behaviors, they have been associated with both genders. This trend is less pronounced in the case of female respondents, who attributed effective behaviors as being specific either to both genders or to male leaders, rather to female leaders. However, there is a clear tendency of female leaders to associate inefficient behaviors with masculine gender, which leads to the idea that gender stereotypes are present in the studied institutions at a pretty high intensity. Moreover, how women have attributed those effective leadership behaviors may be driven by a greater degree of objectivity on their part and a lower level of prejudice and stereotypical thinking. Another possibility would be that women would have more negative perceptions of female leaders than men, and for this reason, a clear tendency to associate effective behaviors with feminine gender could not be observed.

The presence of gender stereotypes in a feminine working field as the public administration will have a negative impact on leader-member relations and also could affect leadership effectiveness. Female civil servants in leadership positions within the studied institutions are represented in a high proportion. If their subordinates consider that effective leadership behaviors are mostly typically masculine, this will have negative consequences on the perceptions against these leaders. If the civil servants do not associate effective leadership with both genders, it means that they do not appreciate 
their female leaders and that they do not consider them as being as effective as male leaders. Also, this could influence negatively female leaders' capacity of developing subordinates' resilience, as they do not consider them as suitable for leading, as men are. It is recommendable that female leaders should try to improve the relations with their subordinates, involve them more in the decision-making process, and try to use new methods for motivating them. Improving relations with subordinates and raising their motivation, could affect positively the perception about their leadership behaviors, and in time, gender stereotypes will be presented at a lower intensity.

\section{ACKNOWLEDGMENT}

This work was supported by a grant of the Ministry of Research and Innovation, CNCS UEFISCDI, project number PN-III-P4-ID-PCCF-2016-0166, within the PNCDI III project "ReGrowEU - Advancing ground-breaking research in regional growth and development theories, through a resilience approach: towards a convergent, balanced and sustainable European Union”.

\section{REFERENCES}

Abele, A. (2003). The dynamics of masculine-agentic and feminine communal traits: Findings from a prospective study. Journal of Personality and Social Psychology, 85, 768 -776.

Alon, T., Doepke, M., Olmstead-Rumsey, J. \& Tertilt, M. (2020). The impact of COVID-19 on gender equality. National Bureau of Economic Research 26947.

Ayman, R., Korabik, K. \& Morris, S. (2009). Is transformational leadership always perceived as effective? Male subordinates' devaluation of female transformational leaders. Journal of Applied Social Psychology, 39, 852-879.

Bakan, D. (1966). The duality of human existence: An essay on psychology and religion. Chicago, IL: Rand McNally.

Bass, B., M. (2008). The Bass handbook of leadership: Theory, research, \& managerial applications (4th ed.). New York, NY: Free Press.

Brenner, O., C., Tomkiewicz, J. \& Schein, V., E. (1989). The relationship between sex role stereotypes and requisite management characteristics revisited. Academy of Management Journal, 3, 662-669.

Broverman, I., Vogel, S., Broverman, D., Clarkson, F. \& Rosenkrantz, P. (1972). Sex-role stereotypes: A reappraisal. Journal of Social Issues, 28, 59-78.

Burns, J., M. (1978). Leadership. New York, Harper \& Row.

Byron, K. (2007). Male and female managers' ability to read emotions: Relationships with supervisor's performance ratings and subordinates' satisfaction ratings. Journal of Occupational and Organizational Psychology, 80, 713-733.

Carli, L., L. \& Eagly, A., H. (1999). Gender effects on influence and emergent leadership. In G. N. Powell (Ed.), Handbook of gender \& work. (pp. 203-222). Thousand Oaks, CA: Sage.

Cole, G. (2004). Management. Teorie şi practică. Iaşi: Editura Ştiinţa.

Deaux, K. \& Kite, M. (1993). Gender stereotypes. In F. L. Denmark \& M. A. Paludi (Eds.), Psychology of women: A handbook of issues and theories. (pp. 107-139). Westport, CT: Greenwood Press.

Dolan, K. (2014). Gender Stereotypes, Candidate Evaluations, and Voting for Women Candidates What Really Matters? Political Research Quarterly, 67, 96-107.

Eagly, A., H., Johannesen-Schmidt, M., C. \& Van Engen, M. (2003). Transformational, transactional and laissez-faire leadership styles: A meta-analysis comparing women and men. Psychological Bulletin, 129, 569-591.

Eagly, A., H. \& Karau, S., J. (1991). Gender and the emergence of leaders: A meta-analysis. Journal of Personality and Social Psychology, 60, 685-710. 
Eagly, A., H. \& Karau, S., J. (2002). Role congruity theory of prejudice toward female leaders. Psychological Review, 109, 573-598.

Eagly, A., H., Karau, S., J. \& Makhijani, M., G. (1995). Gender and the effectiveness of leaders: A meta-analysis. Psychological Bulletin, 117, 125-145.

Eagly, A., H., Makhijani, M., G. \& Klonsky, B., G. (1992). Gender and the evaluation of leaders: A meta-analysis. Psychological Bulletin, 111, 3-22.

European Commission (2019). Country Report Romania 2019. Including an In-Depth Review on the prevention and correction of macroeconomic imbalances, Retrieved August 20, 2020, from https://ec.europa.eu/info/sites/info/files/file_import/2019-european-semester-country-reportromania_en.pdf.

European Commission (2020). Strategia privind egalitatea de gen: către o Uniune a egalității. Retrieved August 20, 2020, from: https://ec.europa.eu/romania/news/20200305_strategia_privind_egalitatea_de_gen_ro.

European Commission (2016). Gender balance on corporate boards, Europe is cracking the glass ceiling. Retrieved August 20, 2020, from http://ec.europa.eu/ newsroom/document.cfm?doc_id=46280.

European Institute for Gender Equality (2019). National administrations: top two tiers of administrators by function of government. Retrieved August 20, 2020, from https://eige.europa.eu/gender-statistics/dgs/indicator/wmidm_adm_nat_wmid_natadmin.

Fiske, S., T. \& Stevens, L., E. (1993). What's so special about sex? Gender stereotyping and discrimination. In S. Oskamp \& M. Costanzo (Eds.), Gender issues in contemporary society: Applied social psychology annual (pp. 173-196). Newbury, CA: Sage.

Forsyth, D., R., Heiney, M., M. \& Wright, S., S. (1997). Biases in Appraisals of Women Leaders, Group Dynamics: Theory, Research and Practice, 1(1): 98-103.

Garcia-Retamero, R. \& López-Zafra, E. (2006). Prejudice against women in male-congenial environments: Perceptions of gender role congruity in leadership. Sex Roles, 55(1-2): 51-61.

Glomb, T. \& Hulin, C. (1997). Anger and gender effects in observed supervisor-subordinate dyadic interactions. Organizational Behavior and Human Decision Processes, 72, 281-307.

Heilman, M., E., Block, C., J., Martell, R., F. \& Simon, M., C. (1989). Has anything changed? Current characterizations of men, women, and managers. Journal of Applied Psychology, 74(6): 935-942.

Heilman, M., E. (2001). Description and prescription: How gender stereotypes prevent women's ascent up the organizational ladder. Journal of Social Issues, 57, 657-674.

Heilman, M., E., Wallen, A., S., Fuchs, D. \& Tamkins, M., M. (2004). Penalties for success: Reactions to women who succeed at male gender-typed tasks. Journal of Applied Psychology, 89, 416-427.

IPU Parline (2020). Global data on national parliaments, Retrieved August 20, 2020, from https://data.ipu.org/.

Johnson, S., K., Murphy, S., E., Zewdie, S. \& Reichard, R., J. (2008). The strong, sensitive type: Effects of gender stereotypes and leadership prototypes on evaluation of male and female leaders, Organizational behavior and human decision processes, 106, 39-60.

Lewis, G. (2000). Race, gender and social welfare: encounters in a post-colonial society. Cambridge: Polity Press.

Lowe, K., B. \& Galen, K., K. (1996). Effectiveness correlates of transformational and transactional leadership: A meta-analytic review of the MLQ literature. Leadership Quarterly, 7(3), 385.

Marshall, J. (1993). Patterns of Cultural Awareness: Coping Strategies for Women Managers in Long, C. Kahn, S. Women, Work and Coping, Montreal: McGill-Queens University Press.

McKinsey \& Company, (2020). COVID-19 and gender equality: Countering the regressive effects. Retrieved August 22, 2020 from https://www.mckinsey.com/featured-insights/future-ofwork/covid-19-and-gender-equality-countering-the-regressive-effects. 
National Agency of Civil Servants (2019). Raportul privind managementul funcției publice și al funcționarilor publici pe anul 2018, Retrieved August 20, 2020, from http://www.anfp.gov.ro/R/Doc/2019/rapoarte\%202019/Raport\%20privind\%20managementul\% 20func\%C5\%A3iei\%20publice\%20\%C5\%9Fi\%20al\%20func\%C5\%A3ionarilor\%20publici\%2 0pentru\%20anul\%202018.pdf.

National Institute of Statistics, (2019), Women and Men, Work and life partnership. Retrieved August 20, 2020, from https://insse.ro/cms/sites/default/files/field/publicatii/women _and _men_working_and_living_partnership_2019.pdf.

Norris, J., M. \& Wylie, A., M. (1995). Gender stereotyping of the managerial role among students in Canada and the United States. Group \& Organization Management, 20, 167-182.

Offermann, L., R., Kennedy, J., K. \& Wirtz, P., W. (1994). Implicit leadership theories: Content, structure, and generalizability. The Leadership Quarterly, 5, 43-58.

Parks-Stamm, E., J., Heilman, M., E. \& Hearns, K., A. (2008). Motivated to penalize: Strategic rejection of successful women. Personality and Social Psychology Bulletin, 34(2), 237-247.

Petty, M., M. \& Miles, R., H. (1976). Leader sex-role stereotyping in a female-dominated work culture. Personnel Psychology, 29, 393-404.

Powell, G., N., Butterfield, D., A., Alves, J., C. \& Bartol, K., M. (2004). Sex effects in evaluations of transformational and transactional leaders. Academy of Management Proceedings, E1-E6.

Rudman, L., A. (1998). Self-promotion as a risk factor for women: The costs and benefits of counter stereotypical impression management. Journal of Personality and Social Psychology, 74(3), 629-645.

Schein, V., E. (1973). The relationship between sex role stereotypes and requisite management characteristics. Journal of Applied Psychology, 57, 95-100.

Schein, V., E. (1975). The relationship between sex role stereotypes and requisite management characteristics among female managers. Journal of Applied Psychology, 60, 340-344.

Schein, V., E. \& Mueller, R. (1992). Sex role stereotyping and requisite management characteristics: a cross cultural look, Journal of Organizational Behavior, 13, 439-447.

Tomkiewicz, J. \& Adeyemi-Bello, T. (1995). A cross-sectional analysis of the attitudes of Nigerians and Americans toward women as managers. Journal of Social Behavior and Personality, 10, 189-198.

Van Engen, M., L., van der Leeden, R. \& Willemsen, T., M. (2001). Gender, context and leadership styles: A field study, Journal of Occupational and Organizational Psychology, 20, 74.

Williams, J., E. \& Best, D., L. (1990). Measuring sex stereotypes: A multinational study (revised edition). Beverly Hills, CA: Sage Publications.

World Economic Forum (2020). Global Gender Gap Report 2020, Retrieved August 29, 2020, from http://www3.weforum.org/docs/WEF_GGGR_2020.pdf. 